Original Research Paper

\title{
Penyuluhan dan Simulasi Menentukan Tipe dan Dosis Latihan Fisik yang Benar untuk Mencapai Kebugaran Fisik yang Optimal pada Pegawai Rektorat Universitas Mataram
}

\author{
Ida Ayu Eka Widiastuti ${ }^{*}$, Rifana Cholidah ${ }^{2}$, Gede Wira Buanayuda ${ }^{3}$, Ida Bagus Alit ${ }^{4}$ \\ ${ }^{1}$ Department of Physiology, Faculty of Medicine Universitas Mataram, Mataram, Indonesia \\ ${ }^{2}$ Department of Nutrition, Faculty of Medicine Universitas Mataram, Mataram, Indonesia \\ ${ }^{3}$ Department of Internal Medicine, Faculty of Medicine Universitas Mataram, Mataram, Indonesia \\ ${ }^{4}$ Department of Mechanical Engineering, Faculty of Engineering Universitas Mataram, Mataram, Indonesia
}

https://doi.org/10.29303/jpmpi.v3i2.1109

Sitasi: Widiastuti, I. A. E., Cholidah, R., Buanayuda, G. W \& Alit, I. B. (2021). Penyuluhan dan Simulasi Menentukan Tipe dan Dosis Latihan Fisik yang Benar untuk Mencapai Kebugaran Fisik yang Optimal pada Pegawai Rektorat Universitas Mataram. Jurnal Pengabdian Magister Pendidikan IPA 4(4)

\section{Article history}

Received: 02 Oktober 2021

Revised: 20 Oktober 2021

Accepted: 07 November 2021

*Corresponding Author: Ida Ayu Eka Widiastuti,

Department of Physiology, Faculty of Medicine

Universitas Mataram, Mataram, Indonesia;

Email: ayueka@unram.ac.id

\begin{abstract}
One of the efforts made to get a healthy condition is to do regular physical exercise. Regular and measurable exercise will result in optimal physical fitness. Physical exercise is done regularly, according to the needs of each individual and by applying the basic principles of exercise, various benefits will be obtained for the body. The purpose of this activity is to educate and increase target knowledge in determining the type of physical exercise and preparing the correct dose of physical exercise to achieve optimal physical fitness. The participants were the Rectorate Staff of the University of Mataram, totaling 40 people, consisting of 14 men and 26 women. The activity lasted for approximately 120 minutes, located in the Ruang Sidang Utama of the Rectorate of the University of Mataram. The implementation of the activity consists of 5 stages, namely: (1) pretest, (2) delivery of counseling material, (3) simulation of determining the type and dose of physical exercise, (4) discussion, and (5) posttest. From the results of this activity, an increase in the knowledge of participants in the activity was obtained by $38.6 \%$, based on the posttest to pretest scores. Participants have an idea in determining the type of physical exercise and determining the appropriate dose of physical exercise for each of them.
\end{abstract}

Keywords: Physical exercise; Type of physical exercise; Dose of physical exercise; Physical fitness.

kewaspadaan tanpa merasa kelelahan yang tidak semestinya serta memiliki energi yang cukup untuk menikmati waktu luang atau menghadapi keadaan darurat yang tidak terduga (Caspersen, Powell, and Christenson, 1985; Thompson, 2014).

Latihan fisik adalah aktivitas fisik yang terencana, terstruktur, berulang, dan bertujuan untuk meningkatkan atau memelihara satu atau lebih komponen kebugaran fisik. Dengan demikian latihan fisik merupakan bagian dari aktivitas fisik dan dapat merupakan seluruh atau sebagian dari setiap kategori aktivitas sehari-hari, kecuali tidur 
(Caspersen, Powell, and Christenson, 1985). World Health Organization (WHO) mendefinisikan olahraga sebagai salah satu subkategori aktivitas fisik yang direncanakan, terstruktur, repetitif dan bertujuan untuk meningkatkan satu atau lebih komponen kebugaran tubuh contoh (WHO, 2020).

Latihan fisik yang dilakukan secara teratur, sesuai dengan kebutuhan masing-masing individu dan dengan menerapkan prinsip dasar latihan, maka akan diperoleh berbagai manfaat bagi tubuh. Manfaat yang diperoleh berkaitan erat dengan tipe atau jenis latihan fisik atau olahraga yang dilakukan. Misalnya latihan kekuatan/ketahanan akan meningkatkan massa otot tanpa lemak, meningkatkan kepadatan mineral tulang, dan meningkatkan sensitivitas insulin, latihan aerobik mampu memperbaiki profil lipid, menurunkan berat badan, dan meningkatkan fungsi kognitif, latihan keseimbangan akan mengurangi risiko jatuh, terutama pada lansia, serta meningkatkan kekuatan dan stabilitas tubuh. Namun demikian untuk semua jenis latihan fisik bermanfaat untuk mengurangi risiko diabetes, kanker, penyakit jantung, dan stres (Oberg, 2007).

Secara khusus, latihan fisik untuk meningkatkan performa olahraga berbeda dengan latihan fisik yang bertujuan untuk meningkatkan/mempertahankan kesehatan. Latihan fisik yang bertujuan untuk meningkatkan performa olahraga, umumnya dengan menggunakan intensitas yang lebih tinggi, yang dilakukan tiap hari, bahkan 2 kali sehari. Prinsip FITT (Frequency, Intensity, Time, Type), merupakan akronim yang lazim digunakan dalam peresepan latihan fisik (Foss and Kateyian, 1998).

Sebagian orang beranggapan bahwa dengan berolahraga yang berat dan lama maka manfaat yang diperoleh semakin besar. Olahraga yang dilakukan tanpa prinsip peresepan yang benar dapat menyebabkan cedera maupun menimbulkan masalah kesehatan. Dosis olahraga dipengaruhi beberapa faktor, antara lain usia, jenis kelamin, status kesehatan individu, dan tujuan dari dilakukannya olahraga tertentu.

\section{Metode}

Kegiatan pengabdian masyarakat ini dilaksanakan dengan menggunakan metode (1) penyuluhan; materi penyuluhan disampaikan dalam bentuk power point (ppt), Materi yang disampaikan adalah: pengertian, manfaat, dan tipe latihan fisik, peresepan latihan fisik yang optimal, prinsip FITT + $\mathrm{P}$ (Frequency, Intensity, Time, Type plus Progression), prinsip peresepan latihan fisik, dan hambatan melakukan latihan fisik. Sebelum dan sesudah dilakukan penyuluhan diberikan soal pre dan posttest yang wajib dikerjakan oleh peserta, (2) simulasi penentuan tipe dan dosis latihan fisik yang benar, dan (3) tanya jawab dan diskusi; memberikan kesempatan kepada peserta untuk memahami dengan lebih baik materi yang disampaikan, mengkonfrmasi hal-hal yang masih kurang dipahami.

\section{Hasil dan Pembahasan}

Kegiatan pengabdian masyarakat dengan sasaran pegawai Rektorat Universitas Mataram. Kegiatan yang mengambil tempat di ruang sidang utama Rektorat Universitas Mataram ini diikuti oleh 40 orang pegawai dari berbagai bagian/unit kerja, yang terdiri dari 14 laki-laki dan 26 perempuan. Kegiatan ini dilaksanakan pada Jumat, 22 Oktober 2021, berlangsung selama kurang lebih 120 menit, dari jam 08.30 hingga jam 10.30 WITA. Pelaksanaan kegiatan terbagi dalam 5 tahap/subkegiatan, yaitu pretest, penyampaian materi penyuluhan, simulasi penentuan tipe dan dosis latihan olahraga, tanya jawab dan diskusi, serta posttest.

Soal pretest terdiri dari 5 pertanyaan benarsalah diberikan sebelum penyampaian materi untuk mengukur prior knowledge yang dimiliki peserta. Peserta kegiatan mengerjakan soal pretest selama 5 (lima) menit. Rerata nilai pretest adalah 70. Setelah mendapatkan materi penyuluhan dan simulasi, peserta diwajibkan mengerjakan posttest dengan soal yang sama dengan pretest. Hasil posttest menunjukkan adanya peningkatan nilai yang diperoleh peserta, dengan rerata nilai 97. Dengan demikian terjadi peningkatan sebesar 38,6\%.

Materi penyuluhan dalam bentuk power point (ppt), disampaikan dengan durasi sekitar 30 menit. Materi penyuluhan yang diberikan terdiri dari: pengertian, manfaat, dan tipe latihan fisik, peresepan latihan fisik yang optimal, prinsip FITT + $\mathrm{P}$ (Frequency, Intensity, Time, Type plus Progression), simulasi peresepan latihan fisik dalam seminggu, dan hambatan melakukan latihan fisik. Materi disampaikan secara lisan dengan menggunakan komunikasi 2 arah, dimaksudkan 
untuk mengakomodir kekurangpahaman peserta terhadap materi yang disampaikan dan membuka kesempatan seluas-luasnya kepada peserta untuk mendapatkan pengetahuan yang memadai tentang materi yang disuluhkan. Pasca penyampaian materi, dilanjutkan dengan sesi tanya jawab dan diskusi.

Pada sesi tanya jawab dan diskusi, peserta kegiatan diberikan kesempatan untuk menanyakan hal-hal terkait materi yang disampaikan. Sesi ini berlangsung selama kurang lebih 20 menit. Antusiasme peserta cukup baik. Hal ini dapat disimpulkan dari cukup banyaknya jumlah penanya. Ada 8 peserta yang menyampaikan pertanyaan. Pertanyaan yang diajukan variatif, lebih banyak terkait peresepan dan dosis latihan fisik yang tepat serta tipe latihan fisik yang sesuai bagi mereka.

Kegiatan pengabdian masyarakat yang dilakukan oleh tim pengabdian yang terdiri dari 3 orang ini menyasar para pegawai Rektorat Universitas Mataram. Pemilihan sasaran kegiatan ini didasarkan pada fakta yang ada bahwa para pegawai cukup banyak menghabiskan waktu duduk selama bekerja dengan jam kerja 8 jam per hari, senin sampai dengan sabtu, sehingga dapat diasumsikan bahwa waktu yang tersedia untuk melakukan latihan fisik cukup terbatas. Data penelitian menunjukkan bahwa kurangnya aktivitas fisik menyebabkan sekitar satu dari setiap 10 kematian setiap tahun, dan menyumbang 6-10\% dari penyakit tidak menular utama di seluruh dunia (Lee, et al., 2012).

Tujuan dari kegiatan ini terutama adalah untuk memberikan pemahaman berkenaan dengan pentingnya melakukan latihan fisik untuk mencapai kebugaran jasmani yang optimal. Kebugaran jasmani yang optimal didefinisikan sebagai kemampuan seseorang dalam melakukan pekerjaan sehari - hari dengan penuh semangat dan kewaspadaan tanpa merasa kelelahan yang tidak semestinya serta memiliki energi yang cukup untuk menikmati waktu luang atau menghadapi keadaan darurat yang tidak terduga terduga (Caspersen, Powell, and Christenson, 1985; Thompson, 2014). Di samping itu dengan materi simulasi merencanakan dosis/peresepan latihan fisik yang benar diharapkan peserta memiliki pengetahuan dan kemampuan membuat program latihan fisiknya secara mandiri untuk dapat diterapkan dalam kehidupan sehari-hari.
Salah satu indikator keberhasilan kegiatan penyuluhan adalah peningkatan pengetahuan peserta kegiatan, yang salah satunya dapat diukur secara sederhana melalui pemberian soal/tes sebelum dan setelah penyampaian materi. Berdasarkan hasil analisis dari nilai pre dan posttest yang diperoleh, terdapat peningkatan pengetahuan para peserta terhadap materi yang disampaikan. Rerata nilai pretest adalah 70, sedangkan nilai posttest meningkat menjadi 97 , terjadi peningkatan sebesar 38,6\%.

Penyampaian materi penyuluhan dan simulasi disampaikan secara sistematis dengan harapan memudahkan pemahaman peserta. Pada slide pembuka disampaikan bahwa latihan fisik/olahraga merupakan obat (exercise is medicine). Dengan pernyataan ini diharapkan perhatian peserta akan lebih terfokus dan lebih tertarik untuk mendengarkan dengan seksama penyampaian materi pada slide-slide selanjutnya. Keingintahuan peserta kegiatan tercermin dengan banyaknya pertanyaan yang diajukan dan sebagain besar ditujukan untuk diri mereka sendiri. Beberapa pertanyaan juga bersifat konfirmatif terhadap praktik latihan fisik yang telah mereka lakukan selama ini, terutama berkenaan dengan dosis dan ketepatan tipe latihan yang dilakukan.

Kegiatan penyuluhan dan simulasi ini selesai sesuai waktu yang direncanakan. Semua pertanyaan dapat terakomodir dengan baik. Pada akhir kegiatan, narasumber dan tim menekankan beberapa poin penting terkait materi yang telah disampaikan serta menekankan kembali tentang pentingnya melakukan latihan fisik secara teratur dan terus menerus untuk mendapatkan manfaat kesehatan yang optimal.

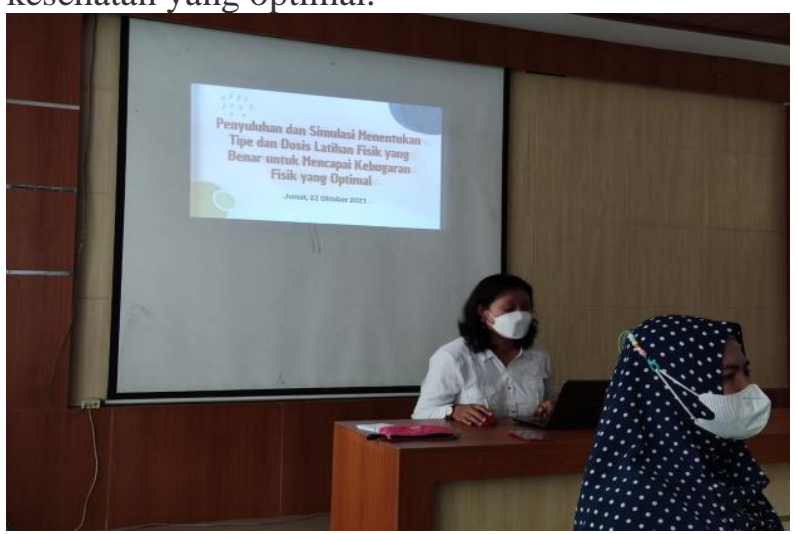

Gambar 1. Pembukaan 


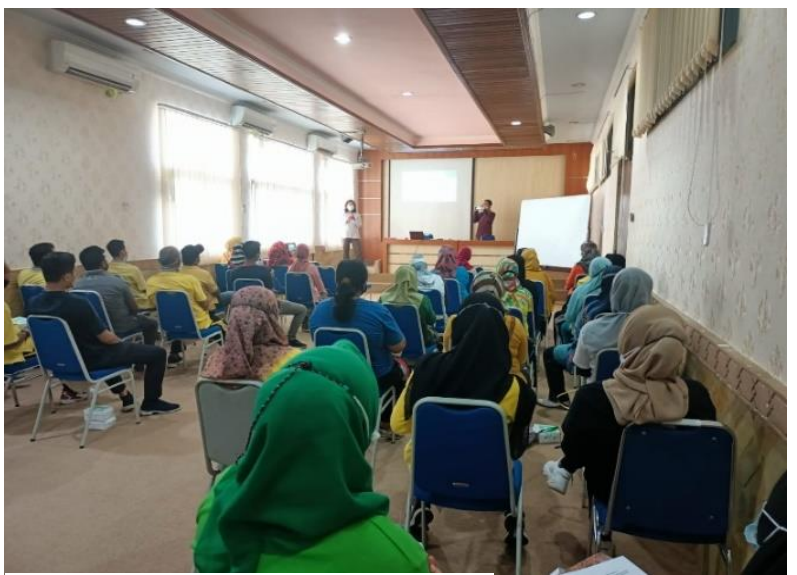

Gambar 2. Penyampaian Materi

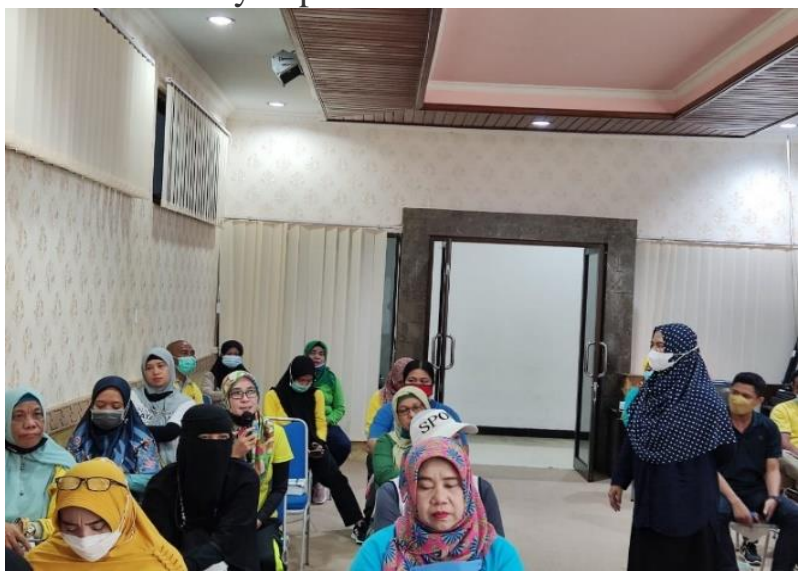

Gambar 3. Diskusi dan Tanya Jawab

\section{Kesimpulan}

Kegiatan penyuluhan dan simulasi ini meningkatkan pengetahuan dan pemahaman peserta tentang pentingnya melakukan latihan fisik yang teratur dengan tipe serta dosis latihan yang benar.

\section{Ucapan Terima Kasih}

Penulis mengucapakan terima kasih kepada pihak Rektorat Universitas Mataram, khususnya bagian Kepegawaian atas dukungannya sehingga kegiatan pengabdian ini dapat terselenggara dengan baik.

\section{Daftar Pustaka}

Caspersen, C. J., Powell, K. E., and Christenson, G. M. (1985). 'Physical Activity, Exercise, and Physical Fitness: Definitions and Distinctions for Health-Related Research', Public Heart Report, 100(2). doi: $10.1177 / 2158244017712769$.
Foss, M.L., Kateyian S.J. (1998). Fox's Physiological Basic for Exercise and Sport. $6^{\text {th }}$ Edition, New York: Mc. Graw Hill Companies Inc.

Lee, I.M., Shiroma, E.J., Lobelo, F., et al. (2012). Effect of physical inactivity on major noncommunicable diseases worldwide: an analysis of burden of disease and life expectancy. The Lancet, Vol. 380, Issue 9838, pp. 219-229.

Oberg, W. (2007). Physical activity prescription: our best medicine. Integrative Medicine, Vol. 6, No. 5, pp. 18-22

Thompson, P. (2014) 'Benefits and risks associated with physical activity', ACSM's Guidelines For Exercise Testing and Prescription, p. 3.

WHO. (2010) Global recommendations on physical activity for health. World Health Organization. 